\title{
Leptin Inhibits Gastric Emptying in Rats: Role of CCK Receptors and Vagal Afferent Fibers
}

\author{
B. ÇAKIR, Ö. KASIMAY, E. DEVSEREN, B. Ç. YEĞEN \\ Department of Physiology, Faculty of Medicine, Marmara University, Istanbul, Turkey
}

Received September 21, 2005

Accepted March 29, 2006

On-line available June 22, 2006

\begin{abstract}
Summary
Leptin regulates energy homeostasis and body weight by balancing energy intake and expenditure. It was recently reported that leptin, released into the gut lumen during the cephalic phase of gastric secretion, is capable of initiating intestinal nutrient absorption. Vagal afferent neurons also express receptors for both CCK and leptin, which are believed to interact in controlling food intake. The present study was undertaken to investigate the central and peripheral effects of leptin on gastric emptying rate. Under anesthesia, male Sprague-Dawley rats (250-300 g) were fitted with gastric Gregory cannulas $(\mathrm{n}=12)$ and some had additional cerebroventricular cannulas inserted into their right lateral ventricles. Following recovery, the rate of gastric emptying of saline $\left(300 \mathrm{mOsm} / \mathrm{kg} \mathrm{H}_{2} \mathrm{O}\right)$ was determined after instillation into the gastric fistula $\left(3 \mathrm{ml}, 37^{\circ} \mathrm{C}\right.$, containing phenol red, $60 \mathrm{mg} / 1$ as a non-absorbable dilution marker). Gastric emptying rate was determined from the volume and phenol red concentrations recovered after 5 min. Leptin, injected intraperitoneally (ip; 10, 30,60,100 $\mu \mathrm{g} / \mathrm{kg}$ ) or intracerebroventricularly (icv; $5,15 \mu \mathrm{g} / \mathrm{rat}$ ) $15 \mathrm{~min}$ before the emptying, delayed gastric emptying rate of saline at the dose of $30 \mu \mathrm{g} / \mathrm{kg}$ or $15 \mu \mathrm{g} / \mathrm{rat}(\mathrm{p}<0.001)$. When $\mathrm{CCK}_{1}$ receptor blocker L-364,718 (1 mg/kg, ip), $\mathrm{CCK}_{2}$ receptor blocker L-365,260 (1 mg/kg, ip) or adrenergic ganglion blocker bretylium tosylate $(15 \mathrm{mg} / \mathrm{kg}$, ip) was administered $15 \mathrm{~min}$ before ip leptin $(30 \mu \mathrm{g} / \mathrm{kg})$ injections, leptin-induced delay in gastric emptying was abolished only by the $\mathrm{CCK}_{1}$ receptor blocker $(\mathrm{p}<0.001)$. However, the inhibitory effect of central leptin on gastric emptying was reversed by adrenergic blockade, but not by either CCK antagonists. Our results demonstrated that leptin delays gastric emptying. The peripheral effect of leptin on gastric motility appears to be mediated by $\mathrm{CCK}_{1}$ receptors, suggesting the release of $\mathrm{CCK}$ and the involvement of vagal afferent fibers. On the other hand, the central effect of leptin on gastric emptying is likely to be mediated by adrenergic neurons. These results indicate the existence of a functional interaction between leptin and CCK receptors leading to inhibition of gastric emptying and short-term suppression of food intake, providing an additional feedback control in producing satiety.
\end{abstract}

\section{Key words}

Capsaicin-sensitive vagal fibers $\bullet \mathrm{CCK} \bullet$ Adrenergic $\bullet$ Gastric emptying $\bullet$ Leptin

\section{Introduction}

Leptin, the protein product of the $o b$ gene, is an adipose tissue derived circulating hormone, which serves as a feedback signal for body weight regulation and energy balance (Zhang et al. 1994, Frederich et al. 1995, 
Campfield et al. 1995) through its receptors (Ob-Rs) in the brain and in the peripheral tissues (Mercer et al. 1996). Although it is synthesized and secreted predominantly by the adipose tissue, leptin and leptin receptor isoforms have been reported in a wide variety of human and rodent tissues (Tartaglia et al. 1995, Hoggard et al. 1997, Mix et al. 1999, Hardwick et al. 2001), suggesting that leptin may have additional peripheral actions other than body fat mass regulation. Defects in the leptin signaling system results in obesity in rodents (Zhang et al. 1994), while the central or peripheral administration of leptin reduces food intake (Flynn et al. 1998, Holzer 2002). Since it is well known that alterations in food intake are associated with changes in gastric emptying (Moran and McHugh 1982), it is likely that leptin suppresses gastric emptying. However, despite previous observations, which demonstrated the inhibitory effect of leptin on gastric emptying (Smedh et al. 1998, Martinez et al. 1999), Barrachina et al. (1997a,b) have reported that the food intake-reducing effect of leptin was not always accompanied by delayed gastric emptying.

Previous studies have shown that exogenous leptin synergistically interacts with cholecystokinin (CCK) to increase vagal afferent activities (Wang et al. 1997, Gaige et al. 2002) and leads to suppression of food intake (Wang et al. 1998, Matson et al. 2000), which is mediated by $\mathrm{CCK}_{1}$ receptors and capsaicin-sensitive afferents (Barrachina et al. 1997a, b). There is a large body of evidence demonstrating that CCK potently reduces the size of the meal (Ritter et al. 1999) and contributes to the regulation of body weight (Matson and Ritter 1999, Matson et al. 2000). Moreover, rats lacking the $\mathrm{CCK}_{1}$ receptors are hyperphagic and obese (Moran et al. 1998). In addition to their synergistic interaction in reducing food intake, it is also reported that both CCK and leptin afford similar gastroprotective (Konturek et al. 1998) and anti-inflammatory activities (Bozkurt et al. 2003). Plasma leptin levels were also shown to be elevated by exogenous CCK administration (Konturek et al. 1998) or vice versa (Gaige et al. 2002).

Factors that yield the changes in gastric emptying are commonly associated with the control of food intake. Although previous studies have shown the gastric inhibitory effect of leptin, which accompanies its anorexic effect, the mechanisms through which leptin affects gastric emptying remain to be determined. Thus, the present study was undertaken to assess the effect of centrally or peripherally administered leptin on gastric emptying rate. Since CCK and leptin have synergistic effects in several functions, our aim was also to identify the involvement of specific CCK receptors and vagal afferent fibers in the action of leptin on gastric emptying.

\section{Methods}

\section{Animals}

Adult male Sprague-Dawley rats weighing 250-300 g were housed individually in a light- and temperature-controlled room on a 12:12-h light-dark cycle, where the temperature $\left(22 \pm 2{ }^{\circ} \mathrm{C}\right)$ and relative humidity $(65-70 \%)$ were kept constant. The animals were fed a standard pellet lab chow, which was withdrawn overnight before preparative surgery and emptying experiments, but access to water was allowed ad libitum. Experiments were approved by the Marmara University School of Medicine Animal Care and Use Committee.

\section{Surgery}

Rats were anesthetized by intraperitoneal (ip) injection of a mixture of ketamine $(100 \mathrm{mg} / \mathrm{kg})$ and chloropromazine $(0.75 \mathrm{mg} / \mathrm{kg})$ and aseptically prepared for abdominal surgery. A small stainless steel Gregory cannula was installed in the corpus as previously described (Dimaline et al. 1986). The cannula was exteriorized through a midline stab incision and the paramedian incision was closed in layers. Rats were housed individually and allowed to recover for 2-3 weeks before the experiments were commenced. During this time, rats were accustomed to light restraint in Bollman cages for 1-2 h every day.

Three weeks after the implantation of the gastric cannula, a group of rats were anesthetized $(100 \mathrm{mg} / \mathrm{kg}$ ketamine and $0.75 \mathrm{mg} / \mathrm{kg}$ chlorpromazine, ip) and placed on a stereotaxic instrument (Stoelting Lab standard stereotaxic instrument). The rats were fitted with stainless steel cerebroventricular guide cannulas (22-gauge; Plastic Products, Roanoke, VA) inserted into the right lateral cerebral ventricle $(1.1 \mathrm{~mm}$ caudal and $1.5 \mathrm{~mm}$ lateral to the bregma, $3.2 \mathrm{~mm}$ ventral to the surface of the skull) according to the atlas of Paxinos and Watson (1986). The cannula was held in place by dental acrylic cement anchored around three stainless steel screws. Three days were allowed before starting the emptying experiments. After each experiment, correct placement of the cannula was verified by injection of methylene blue and brain section. 


\section{Measurement of gastric emptying}

Prior to experiments, rats were fasted overnight and then placed in Bollman cages, the gastric cannulas were opened, the gastric contents were flushed gently with warm physiological saline $\left(0.9 \% \mathrm{NaCl}, 37^{\circ} \mathrm{C}\right)$ and the stomach was allowed to drain freely for $45 \mathrm{~min}$. The rate of gastric emptying of saline $(0.9 \% \mathrm{NaCl}$, $300 \mathrm{mOsm} / \mathrm{kg}$ ) was examined using methods described previously (Green et al. 1988). Physiological saline ( $3 \mathrm{ml})$ containing phenol red (PR; $60 \mathrm{mg} / \mathrm{l}$ ) as a nonabsorbable marker was instilled into the gastric cannula, and the gastric emptying rate $(\mathrm{ml} / 5 \mathrm{~min})$ was determined from the volume and phenol red concentrations recovered from the cannula $5 \mathrm{~min}$ after instillation of saline. Phenol red concentration was determined spectrophotometrically from the absorbances read at $550 \mathrm{~nm}$, as described by Debas et al. (1975). Gastric emptying ( $\mathrm{E} ; \mathrm{ml} / 5 \mathrm{~min})$ is calculated from the absorbances (A1: absorbance of instilled solution; A2: absorbance of collected fluid) and volumes (V1: volume of instilled solution; V2: volume of collected fluid) according to the following formula:

$$
\mathrm{E}=[(\mathrm{V} 1 \times \mathrm{A} 1)-(\mathrm{V} 2 \times \mathrm{A} 2)] /(\mathrm{A} 1+\mathrm{A} 2)
$$

\section{Vagal afferent denervation with capsaicin}

In order to study the involvement of vagal afferent fibers, on the day of the gastric cannula placement, a group of rats had local application of capsaicin on the vagal nerves. Rats were anesthetized and pretreated with atropine sulfate $(2 \mathrm{mg} / \mathrm{kg}$, ip) to decrease the acute effects of capsaicin on the respiratory and cardiovascular systems. A $1 \%$ solution of capsaicin (Sigma) or vehicle (10\% Tween 80 in oil, shamdenervation) was applied on each vagus nerve in turn for $30 \mathrm{~min}$. The total dose of capsaicin applied in each rat did not exceed $1 \mathrm{mg}$. Following the application, the area was rinsed with sterile saline. Animals were used in the emptying experiments 3 weeks after the capsaicin treatment. The efficacy of perivagal capsaicin treatment was assessed previously by the sulfated CCK satiety test (Mazelin et al. 1998).

\section{Drugs}

Leptin (Sigma, St. Louis, MO) was dissolved in $0.1 \%(\mathrm{w} / \mathrm{v})$ bovine serum albumin (BSA, Sigma) and aliquots were stored at $-20{ }^{\circ} \mathrm{C}$ until use. Leptin or vehicle (BSA) was administered intraperitoneally (ip; 10, 30, 60, $100 \mu \mathrm{g} / \mathrm{kg}$ ) or intracerebroventricularly (icv; 5, $15 \mu \mathrm{g} / \mathrm{rat}$ ) $15 \mathrm{~min}$ before performing gastric emptying studies. $\mathrm{CCK}_{1}$ receptor antagonist L-364,718 (1 mg/kg, a generous gift from ML Laboratories, PLC, London, UK) and $\mathrm{CCK}_{2}$ receptor antagonist L-365,260 (1 $\mathrm{mg} / \mathrm{kg}, \quad \mathrm{ML}$ Laboratories) were freshly prepared in $3.3 \%$ dimethyl sulfoxide (DMSO, Sigma), while the sympathetic ganglion blocker bretylium tosylate $(15 \mathrm{mg} / \mathrm{kg}$; American Reagent Laboratories) was prepared in saline. CCK antagonists, sympathetic ganglion blocker bretylium tosylate or saline were given ip $15 \mathrm{~min}$ before leptin injections. Doses of the antagonists were chosen depending on the previous reports, in which they were found to be effective in reversing the gastric effects of the agonists. Previously, we have found that the gastric emptying rate in saline- or DMSO-treated rats does not differ.

\section{Statistical analysis}

The results are expressed as means \pm S.E.M. with 6 rats per group. Instat statistical package (GraphPad Software, San Diego, CA, USA) was used. Following the assurance of normal distribution of data, one-way analysis of variance (ANOVA) was used for multiple comparisons and Student's t-test was used to evaluate the level of statistical significance between two groups. Differences were considered statistically significant if $\mathrm{p}<0.05$.

\section{Results}

In control rats with a gastric fistula, the emptying of saline $(3.05 \pm 0.04 \mathrm{ml} / 5 \mathrm{~min})$ was rapid and similar to that described previously (Forster et al. 1991). Intraperitoneal administration of leptin resulted in significant $(\mathrm{p}<0.001)$ inhibition of saline emptying at only the $30 \mu \mathrm{g} / \mathrm{kg}$ dose $(2.41 \pm 0.07 \mathrm{ml} / 5 \mathrm{~min})$ (Fig. 1), whereas neither the lower $(10 \mu \mathrm{g} / \mathrm{kg})$ nor the higher doses (60 and $100 \mu \mathrm{g} / \mathrm{kg}$ ) affected saline emptying. To investigate the participating mechanisms in leptininduced delay in gastric emptying, the subsequent emptying experiments were continued with the effective dose $(30 \mu \mathrm{g} / \mathrm{kg})$. On the other hand, cerebroventricular administration of leptin at $15 \mu \mathrm{g} / \mathrm{rat}$ dose significantly $(2.05 \pm 0.07 \mathrm{ml} / 5 \mathrm{~min} ; \mathrm{p}<0.001)$ delayed gastric emptying of saline.

Peripheral administration of $\mathrm{CCK}_{1}$ receptor antagonist, $\mathrm{CCK}_{2}$ receptor antagonist, sympathetic ganglion blocker or the respective vehicles did not influence the gastric emptying rate of saline (data not shown). $\mathrm{CCK}_{2}$ receptor antagonist significantly reversed 


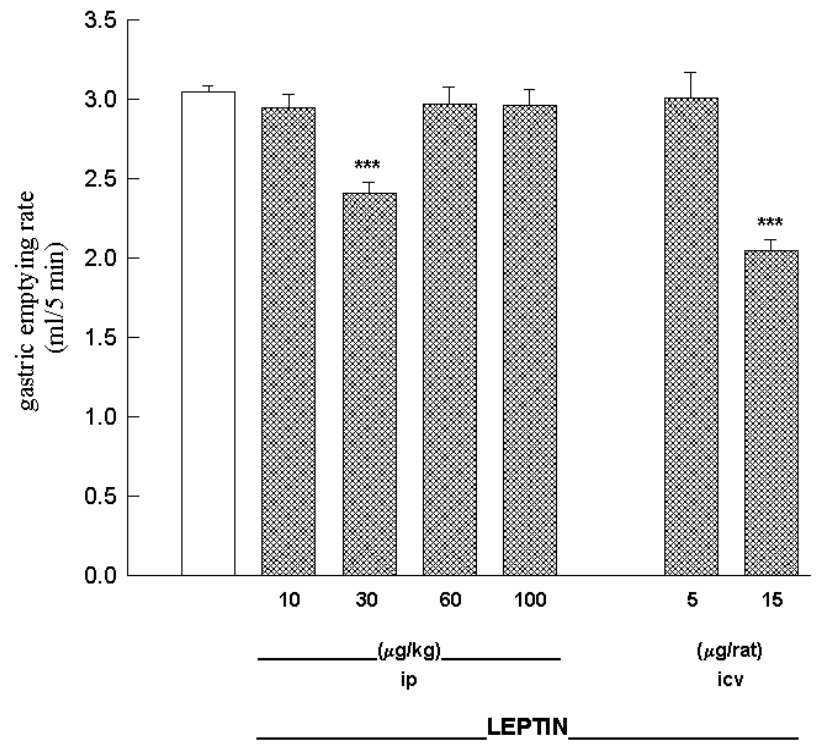

Fig. 1. Effects of intraperitoneal (ip) or intracerebroventricular (icv) administration of leptin on gastric emptying rate of saline $(0.9 \% \mathrm{NaCl}, 300 \mathrm{mOsm} / \mathrm{kg})$ in rats with gastric cannulas. $* * * p<0.001$; compared to control group treated with vehicle (bovine serum albumin). Each group consists of 6 animals.

(2.71 $\pm 0.09 \mathrm{ml} / 5 \mathrm{~min} ; \mathrm{p}<0.05)$, while $\mathrm{CCK}_{1}$ receptor antagonist abolished $(3.16 \pm 0.19 \mathrm{ml} / 5 \mathrm{~min} ; \mathrm{p}<0.001)$ the suppression of gastric emptying rate induced by intraperitoneal leptin administration (Fig. 2a). Topical capsaicin application, which was performed to clarify the role of vagal afferent fibers in the peripheral action of leptin, reversed the inhibitory effect of ip leptin significantly $(2.75 \pm 0.05 \mathrm{ml} / 5 \mathrm{~min} ; \mathrm{p}<0.01)$ (Fig. $2 \mathrm{a})$. On the other hand, perivagal capsaicin had no significant effect on saline emptying in BSA-treated rats (data not shown).

Neither $\mathrm{CCK}_{1}$ - nor $\mathrm{CCK}_{2}$-receptor antagonist influenced the delayed gastric emptying rate induced by icv leptin (Fig. 2b). Blockade of the sympathetic ganglia had no significant effect on the inhibitory role of peripherally administered leptin, while the delayed gastric emptying rate induced by icv leptin was significantly reversed $(2.55 \pm 0.17 \mathrm{ml} / 5 \mathrm{~min} ; \quad \mathrm{p}<0.01)$ by the sympathetic ganglion blocker.

\section{Discussion}

There is evidence of synergistic interaction between peripheral leptin and CCK in the short-term modulation of food intake, taking place at the level of vagal afferent terminals (Barrachina et al. 1997a, b). This short-term interaction was apparent following a low dose of peripheral leptin, which may act via leptin-sensitive
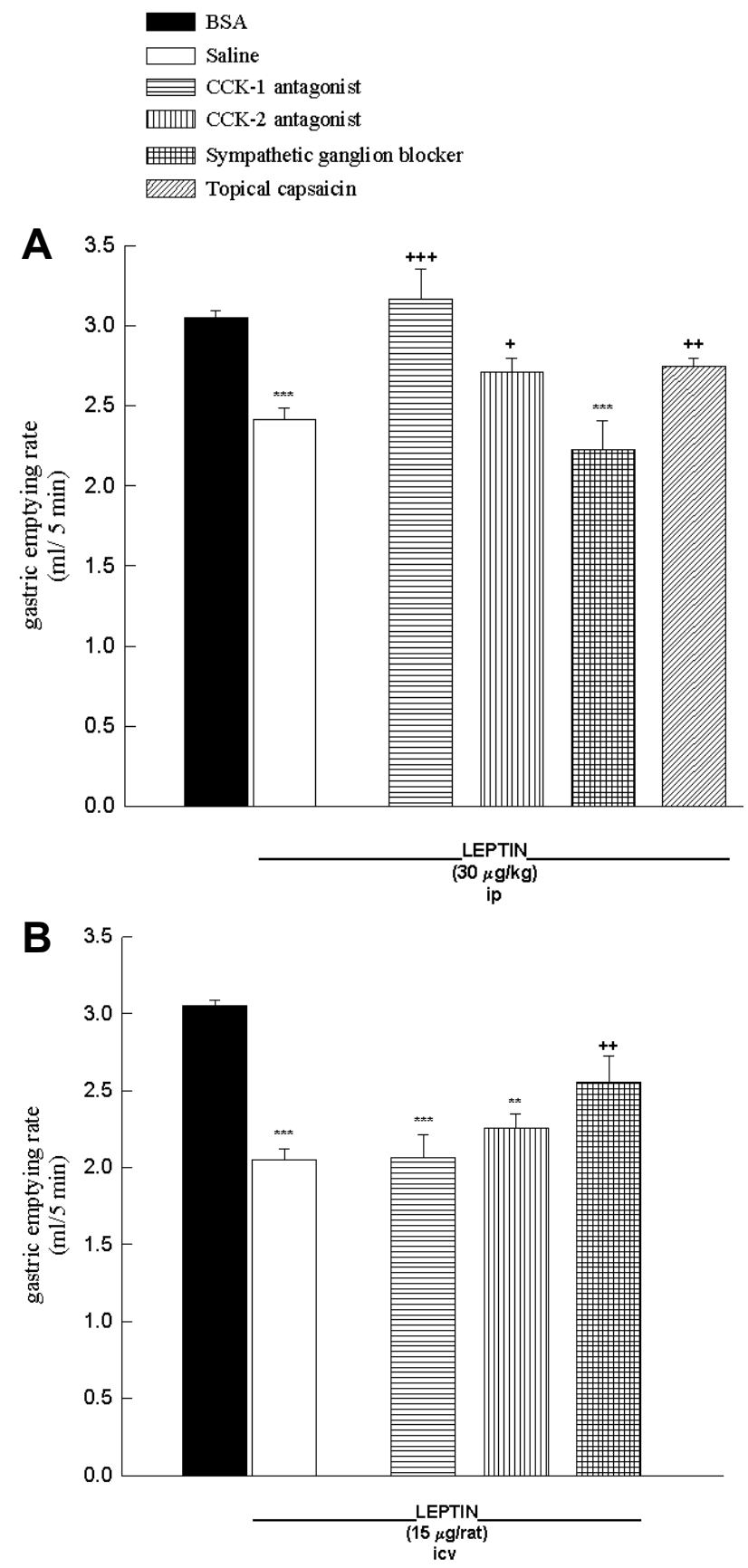

Fig. 2. Effects of (A) intraperitoneal (ip) or (B) intracerebroventricular (icv) administration of leptin in rats pretreated with $\mathrm{CCK}_{1}$ receptor antagonist (L-364,718; $1 \mathrm{mg} / \mathrm{kg}$ ) or $\mathrm{CCK}_{2}$ receptor antagonist (L-365,260; $1 \mathrm{mg} / \mathrm{kg}$ ) or sympathetic ganglion blocker (bretylium tosylate; $15 \mathrm{mg} / \mathrm{kg}$ ) on gastric emptying rate of saline. Topical capsaicin was applied to clarify the role of vagal afferent fibers in the peripheral action of leptin (ip). $* * p<0.01, * * * p<0.001$; compared to control group which received bovine serum albumin $(B S A) .+p<0.05,++p<0.01$, $+++p<0.001$; compared to saline + leptin-treated group. Each group consisted of 6 animals.

vagal afferents to trigger enhanced neuronal activity in the hypothalamus (Wang et al. 1997). In accordance with these studies that characterize the role of CCK in the control of gastric emptying and food intake, current data 
implicate that peripheral administration of leptin may activate the release of CCK from intestinal endocrine cells and initiate a vago-vagal inhibition of the gastric emptying through the $\mathrm{CCK}_{1}$ receptors. On the contrary, the central administration of leptin delays gastric emptying via the activation of adrenergic receptors. However, immunohistochemical studies and tracing methods may be used to elucidate the potential neurohumoral interactions between leptin and CCK in the control of gastric functions.

Central or peripheral administration of leptin reverses the obesity syndrome found in $o b / o b$ mice, stimulates the metabolic rate, and reduces food intake in lean mice and rats (Pelleymounter et al. 1995). Leptin could alter food intake by reducing the appetitive value of food or by inhibiting gastric emptying rate. In accordance with this hypothesis, several other peptides including $\mathrm{CCK}$, calcitonin gene-related peptide and corticotropinreleasing peptide, which are known to decrease food intake, also inhibit gastric transit in rodents (Morley and Levine 1982, Morley et al. 1996, Sheldon et al. 1990). On the other hand, in the rats with ventromedial hypothalamic lesion, overeating and obesity were found to be associated with rapid gastric transit (Duggan and Booth 1986). Similarly, it was recently demonstrated that leptin-deficient obese mice have an increased proximal intestinal transit, but an overall decrease in small intestinal transit (Kiely et al. 2005b). However, Barrachina et al. (1997b) have reported that a single intraperitoneal injection of leptin $(120 \mu \mathrm{g} / \mathrm{kg})$ reduced food intake without a concomitant alteration in the gastric emptying of a solid nutrient meal. On the other hand, the results of the present study demonstrated that one-quarter of that systemic dose, as well as icv administration of leptin, inhibited the gastric emptying rate of a liquid, nonnutrient content, while the higher doses (60 and 100 $\mu \mathrm{g} / \mathrm{kg}$ ) were not effective on gastric emptying rate. As observed in the actions of many peptides, it appears that leptin has a bell-shaped effect on the gastric emptying rate. It may be suggested that the emptying mechanisms involved in nutrient-rich and non-nutrient gastric contents are different and leptin acting as a satiety signal, may be affected with the caloric content of the meal. However, the results suggest that leptin when given at a physiological dose is effective in the inhibition of gastric emptying rate, while the higher anorexogenic doses have no effect on the emptying of either caloric or non-caloric gastric contents.

Previously, it was shown that intracerebro- ventricularly administered leptin inhibits feeding by reducing meal size, but it is not due to a depression of feeding behavior or due to an impairment in the rat's capacity to start a meal (Flynn et al. 1998). In the present study, central leptin administration inhibited gastric emptying rate, implicating a possible role of leptin in controlling meal size. Since leptin decreases appetite and increases basal metabolism (Halaas et al. 1995), the inhibitory effect on gastric emptying rate in this study would be consistent with those two functions in monitoring body weight and composition. Similarly, it was shown that leptin has a rapid inhibitory effect on sugar absorption (Lostao et al. 1998). In the human stomach, it was reported that vagal stimulation rapidly increases leptin secretion during the cephalic phase of gastric secretion and luminal leptin may be involved in nutrient absorption (Sobhani et al. 2002). This means that the inhibitory effect of leptin on food intake and body weight may involve decreased efficiency in the absorption of ingested nutrients with a concomitant reduction in the propogation of luminal contents to the absorptive surfaces.

Leptin-specific receptors have been found to exist in the sympathetic prevertebral ganglionic neurons and in afferent and efferent vagal neurons in rats (Miller et al. 1999, Buyse et al. 2001). When leptin was injected following CCK administration in cats, the small intestinal electromyographic activity was stimulated, while leptin had no effect on this activity in the absence of CCK (Gaige et al. 2003a,b). These findings strongly suggest that the mechanisms whereby leptin along with CCK enhances intestinal motility involve the vago-vagal reflex. Wang et al. (1997) have speculated that after a meal, type 2 gastric vagal afferent (GVA) terminals require CCK to be responsive to circulating leptin and to generate satiety signals. On the other hand, type 1 GVA terminals respond to circulating leptin without an interaction with $\mathrm{CCK}$ and provide a feedback signal for the maintenance of body weight, which appears to be a long-term effect. Therefore, the synergistic effects of CCK and leptin in the modulation of food intake and small intestinal motility are mediated by vagal afferent fibers. In accordance with these studies, the present data confirm that gastric emptying rate is governed by vagal afferent activity. Previous studies have shown the synergistic effects by administering these peptides exogenously. However, the results of the present study implicate that leptin, when administered in relatively lower doses than those used in studying synergistic interaction, acts via the 
CCK receptors that involve the activation of capsaicinsensitive vagal afferent fibers. Thus, leptin-induced delay in gastric emptying via the vagal CCK receptors may constitute a short-term regulatory mechanism that reduces the meal size. This short-term synergy may be mediated by an enhancement of CCK signaling via the vagus in the presence of increased extracellular leptin (Wang et al. 1997). Moreover, Kiely et al. (2005a) have reported a synergistic action of cholecystokinin and leptin in the regulation of small intestinal motility in leptin-deficient obese mice.

Since the leptin-CCK synergy is common in both body weight regulation and gastric emptying, it is likely that similar centers participate in the integration of these functions. It is possible that leptin-initiated vagal stimuli to the NTS may modify gastric motility and gastric emptying, while providing advance signals for body weight regulation. However, the peripherally administered leptin appears to act through a vago-vagal pathway to inhibit gastric emptying via CCK receptors, whereas the inhibitory effect of central leptin on gastric emptying is mediated by sympathetic fibers. Broberger et al. (1998) have reported that the parabrachial nucleus $(\mathrm{PBN})$ in the pons is a potential site for the synergistic interaction between leptin and CCK for integration of satiety signals (Raybould et al. 1998, Tartaglia et al. 1995). Projections from NTS to the dorsal motor vagal nucleus (DMN), the nucleus ambiguus, and the intermediolateral column of the spinal cord form the basis for the vago-vagal and vago-spinal reflexes in the control of gastric fundus tone and antral motility (Rutecki 1990). However, the present data demonstrate that CCK signaling is not essential for the gastric inhibitory effect of centrally administered leptin, while projections from CCK-activated centers may control the gastric motility.

Our results further elucidate the potential interactions between leptin and CCK in the control of gastric functions through the activation of vagal afferent fibers that relay information to brain sites. These results indicate the existence of a functional interaction between leptin and CCK receptors leading to inhibition of gastric emptying and short-term suppression of food intake, providing additional feedback control in producing satiety.

\section{References}

BARRACHINA MD, MARTINEZ V, WANG L, WEI JY, TACHE Y: Synergistic interaction between leptin and cholecystokinin to reduce short-term food intake in lean mice. Proc Natl Acad Sci USA 94: 10455-10460, $1997 \mathrm{a}$.

BARRACHINA MD, MARTINEZ V, WEI JY, TACHE Y: Leptin-induced decrease in food intake is not associated with changes in gastric emptying in lean mice. Am J Physiol 272: R1007-R1011, $1997 \mathrm{~b}$.

BOZKURT A, ÇAKIR B, ERCAN F, YEGEN BC: Anti-inflammatory effects of leptin and cholecystokinin on acetic acid-induced colitis in rats: role of capsaicin-sensitive vagal afferent fibers. Regul Pept 116: 109-118, 2003.

BROBERGER C, JOHANSEN J, JOHANSSON C, SCHALLING M, HOKFELT T: The neuropeptide Y/agouti generelated protein (AGRP) brain circuitry in normal, anorectic and monosodium glutamate-treated mice. Proc Natl Acad Sci USA 95: 15043-15048, 1998.

BUYSE M, OVESJO ML, GOIOT H, GUILMEAU S, PERANZI G, MOIZO L, WALKER F, LEWIN MJ, MEISTER $\mathrm{B}, \mathrm{BADO}$ A: Expression and regulation of leptin receptor proteins in afferent and efferent neurons of vagus nerve. Eur J Neurosci 14: 64-72, 2001.

CAMPFIELD LA, SMITH FJ, GUISEZ Y, DEVOS R, BURN P: Recombinant mouse OB protein: evidence for a peripheral signal linking adiposity and central neural networks. Science 269: 546-549, 1995.

DEBAS HT, FAROOQ O, GROSSMAN MI: Inhibition of gastric emptying is a physiological action of cholecystokinin. Gastroenterology 68: 1211-1217, 1975.

DIMALINE R, CARTER N, BARNES S: Evidence for reflex adrenergic inhibition of acid secretion in the conscious rat. Am J Physiol 251: G615-G618, 1986.

DUGGAN JP, BOOTH DA: Obesity, overeating, and rapid gastric emptying in rats with ventromedial hypothalamic lesions. Science 231: 609-611, 1986.

FLYNN MC, SCOTT TR, PRITCHARD TC, PLATA-SALAMAN CR: Mode of action of OB protein (leptin) on feeding. Am J Physiol 275: R174-R179, 1998. 
FORSTER ER, GREEN T, DOCKRAY GJ: Efferent pathways in the reflex control of gastric emptying in rats. Am $J$ Physiol 260: G499-G504, 1991.

FREDERICH RC, LOLLMANN B, HAMANN A, NAPOLITANO-ROSEN A, KAHN BB, LOWELL B, FLIER JS: Expression of ob mRNA and its encoded protein in rodents. J Clin Invest 96: 1658-1663, 1995.

GAIGE S, ABYSIQUE A, BOUVIER M: Effects of leptin on cat intestinal vagal mechanoreceptors. $J$ Physiol Lond 543: 679-689, 2002.

GAIGE S, ABOU E, ABYSIQUE A, BOUVIER M: Effects of interactions between interleukin- $1 \beta$ and leptin on cat intestinal vagal mechanoreceptors. J Physiol Lond 555: 297-310, 2003a.

GAIGE S, ABYSIQUE A, BOUVIER M: Effects of leptin on cat intestinal motility. J Physiol Lond 546: 267-277, $2003 \mathrm{~b}$.

GREEN T, DIMALINE R, PEIKIN S, DOCKRAY GJ: The action of the cholecystokinin antagonist L364,718 on gastric emptying of liquid meals in the concious rat. Am J Physiol 255: G685-G689, 1988.

HALAAS JL, GAJIWALA KS, MAFFEI M, COHEN SL, CHAIT BT, RABINOWITZ D, LALLONE RL, BURLEY SK, FRIEDMAN JM: Weight-reducing effects of the plasma protein encoded by the obese gene. Science 269: 543-546, 1995.

HARDWICK JC, VAN DEN BRINK GR, OFFERHAUS GJ, VAN DEVENTER SJ, PEPPELENBOSCH MP: Leptin is a growth factor for colonic epithelial cells. Gastroenterology 121: 79-90, 2001.

HOGGARD N, HUNTER L, DUNCAN JS, WILLIAMS LM, TRAYHURN P, MERCER JG: Leptin and leptin receptor mRNA and protein expression in the murine fetus and placenta. Proc Natl Acad Sci USA 94: 1107311078, 1997.

HOLZER P: Gut-Brain Peptides in the New Millenium. CURE Foundation, Los Angeles, 2002, pp 275-284.

KIELY JM, GRAEWIN SJ, PITT HA, SWARTZ-BASILE DA: Leptin increases small intestinal response to cholecystokinin in leptin-deficient obese mice. J Surg Res 124: 146-150, 2005 a.

KIELY JM, NOH JH, GRAEWIN SJ, PITT HA, SWARTZ-BASILE DA: Altered intestinal motility in leptin-deficient obese mice. J Surg Res 124: 98-103, 2005b.

KONTUREK PC, KONTUREK SJ, BRZOZOWSKI T, HAHN EG: Gastroprotection and control of food intake by leptin. Comparison with cholecystokinin and prostaglandins. J Physiol Pharmacol 50: 39-48, 1998.

LOSTAO MP, URDANETA E, MARTINEZ-ANSO E, BARBER A, MARTINEZ JA: Presence of leptin receptors in rat small intestine and leptin effect on sugar absorption. FEBS Lett 423: 302-306, 1998.

MARTINEZ V, BARRACHINA MD, WANG L, TACHE Y: Intracerebroventricular leptin inhibits gastric emptying of a solid nutrient meal in rats. Neuroreport 10: 3217-3221, 1999.

MATSON CA, RITTER RC: Long-term CCK-leptin synergy suggests a role for CCK in the regulation of body weight. Am J Physiol 276: R1038-R1045, 1999.

MATSON CA, REID DF, CANNON TA, RITTER RC: Cholecystokinin and leptin act synergistically to reduce body weight. Am J Physiol 278: R882-R890, 2000.

MAZELIN L, THEODOROU V, MORE J, FIORAMONTI J, BUENO L: Protective role of vagal afferents in experimentally-induced colitis in rats. $J$ Auton Nerv Syst 73: 38-45, 1998.

MERCER JG, HOGGARD N, WILLIAMS LM, LAWRANCE CB, HANNAH LT, MORGAN PJ, TRAYHURN P: Coexpression of leptin receptor and preproneuropeptide Y mRNA in arcuate nucleus of mouse hypothalamus. J Neuroendocrinol 8: 733-735, 1996.

MILLER SM, SCHMALZ PF, BENARROCH EE, SZURSZEWSKI JH: Leptin receptor immunoreactivity in sympathetic prevertebral ganglion neurons of mouse and rat. Neurosci Lett 265: 75-78, 1999.

MIX H, MANNS MP, WAGNER S, WIDJAJA A, BRABANT G: Expression of leptin and its receptor in the human stomach (Letter). Gastroenterology 117: 509, 1999.

MORAN TH, MCHUGH PR: Cholecystokinin suppresses food intake by inhibiting gastric emptying. Am J Physiol 242: R491-R497, 1982.

MORAN TH, KATZ LF, PLATA-SALAMAN CR, SCHWARTZ GJ: Disordered food intake and obesity in rats lacking chocystokinin A receptors. Am J Physiol 274: R618-R625, 1998. 
MORLEY JE, LEVINE AS: Corticotrophin releasing factor, grooming and ingestive behavior. Life Sci 31: 1459-1464, 1982.

MORLEY JE, FARR SA, FLOOD JF: Peripherally administered calcitonin gene-related peptide decreases food intake in mice. Peptides 17: 511-516, 1996.

PAXINOS G, WATSON C: The Rat Brain in Stereotaxic Coordinates. Academic Press, New York, 1986.

PELLEYMOUNTER MA, CULLEN MJ, BAKER MB, HECHT R, WINTERS D, BOONE T, COLLINS F: Effect of the obese gene product on body weight regulation in ob/ob mice. Science 269: 540-545, 1995.

RAYBOULD HE, GAYTON RJ, DOCKRAY GJ: Mechanisms of action of peripherally administered cholecystokinin octapeptide on brainstem neurons in the rat. J Neurosci 8, 3018-3024, 1998.

RITTER RC, COVASA M, MATSON CA: Cholecystokinin: proofs and prospects for involvement in control of food intake and body weight. Neuropeptides 33: 387-399, 1999.

RUTECKI P: Anatomical, physiological, and theoretical basis for the antiepileptic effect of vagus nerve stimulation. Epilepsia 31 (Suppl 2): S1-S6, 1990.

SHELDON RJ, QI JA, PORRECA F, FISHER LA: Gastrointestinal motor effects of corticotropin- releasing factor in mice. Regul Pept 28: 137-151, 1990.

SMEDH U, HAKANSSON ML, MEISTER B, UVNAS-MOBERG K: Leptin injected into the fourth ventricle inhibits gastric emptying. Neuroreport 9: 297-301, 1998.

SOBHANI I, BUYSE M, GOIOT H, WEBER N, LAIGNEAU JP, HENIN D, SOULE JC, BADO A: Vagal stimulation rapidly increases leptin secretion in human stomach. Gastroenterology 122: 259-263, 2002.

TARTAGLIA LA, DEMBSKI M, WENG X, DENG N, CULPEPPER J, DEVOS R, RICHARDS GJ, CAMPFIELD LA, CLARK FT, DEEDS J, MUIR C, SANKER S, MORIARTY A, MOORE KJ, SMUTKO JS, MAYS GG, WOOLF EA, MONROE CA, TEPPER RI: Identification and expression cloning of a leptin receptor, OB-R. Cell 83: 1263-1271, 1995.

WANG L, MARTINEZ V, BARRACHINA MD, TACHE Y: Fos expression in the brain induced by peripheral injection of CCK or leptin plus CCK in fasted lean mice. Brain Res 27: 157-166, 1998.

WANG YH, TACHE Y, SHEIBEL AB, GO VLW, WEI JY: Two types of leptin-responsive gastric vagal afferent terminals: an in vitro single-unit study in rats. Am J Pysiol 273: R833-R837, 1997.

ZHANG Y, PROENCA R, MAFFEI M, BARONE M, LEOPOLD L, FRIEDMAN JM: Positional cloning of the mouse obese gene and its human homologue. Nature 372: 425-432, 1994.

\section{Reprint requests}

Berrak Ç. YEĞEN, Department of Physiology, Marmara University School of Medicine, 34668 Haydarpaşa, İstanbul, Turkey. Fax: 216-418 3327. E-mail: byegen@marmara.edu.tr 